\title{
An Adaptive and Reliable System Based on Interdependence between Agents
}

\author{
Akifumi Tanimoto Non-member (Graduate School of Engineering, Osaka Prefecture University) \\ Keinosuke Matsumoto Member (Graduate School of Engineering, Osaka Prefecture University) \\ Naoki Mori Non-member (Graduate School of Engineering, Osaka Prefecture University)
}

Keywords : Reliability, Robust, Interdependence graph, Monitoring, Replication, Intelligent systems

\section{Multiagent System}

A multiagent system (MAS) has recently gained public attention as a technique to solve competition and cooperation in distributed systems. However, MAS's vulnerability due to the propagation of failures prevents from applying to large scale systems. Then, this paper proposes a general composition technique to improve its reliability easily applied to the existent MAS.

\section{Adaptive Multiagent System}

2.1 Monitoring System Proposed system monitors messages between agents to detect undesirable behaviors (failures). An monitoring mechanism is distributed in order to raise efficiency and reliability. The monitoring system has the following two roles:

- Observation and control of domain agents

- Generation of global information

These two roles are assigned to two kinds of agents: monitoring agents and a host monitoring agent. A monitoring agent is associted with each domain agent, and a host monitoring agent is associted with each monitoring agent, respectively.

2.2 Interdependence Graph Collecting related information, the system generates global information of interdependence between agents and expresses it in a graph. A domain agent is related to a node as shown in Fig. 1. These

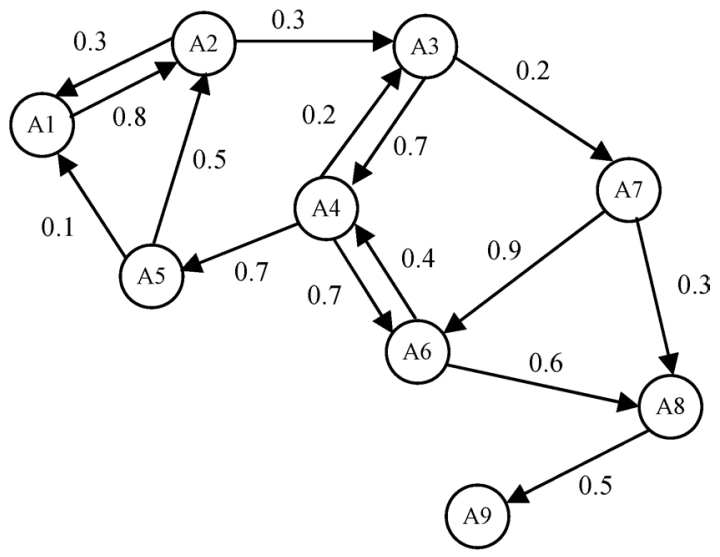

Fig. 1. Interdependence graph situation is expressed as $(N, L, W)$. It is called an interdependence graph.

$$
\begin{aligned}
& N=\{N i\} i=1, \ldots, n \\
& L=\{L i, j\} i=1, \ldots, n, j=1, \ldots, n \\
& W=\{W i, j\} i=1, \ldots, n, j=1, \ldots, n
\end{aligned}
$$

Where, $n$ is the total number of nodes, $N$ is a node set, $L i, j$ is a link from node $\mathrm{Ni}$ to $\mathrm{Nj}$, and $W i, j$ is a weight labelled to a link $L i, j$. Wi,j corresponds to importance of the interdependence between agent $i$ and $j$. Moreover, if domain agentis are added or deleted, the graph is updated dynamically. This interdependence graph enables us to detect or predict undesirable behaviors.

2.3 Adaptive Multiagent Architecture Our adaptive multiagent architecture is shown in Fig. 2. This architecture consists of a monitoring system and a replication server that manages domain agents and replicas. The replication, which arranges replicas of the same contents on a network, is an effective technique for improving the reliability of distributed systems. In our adaptive replication system, you can adjust dynamically the number of replicas according to each agent's importance computable from the interdependence graph.

Our simulations show that the system can optimize performance of a MAS and improve adaptively its reliability under complicated and dynamic environment by applying the global information acquired from the interdependence graph to the replication system.

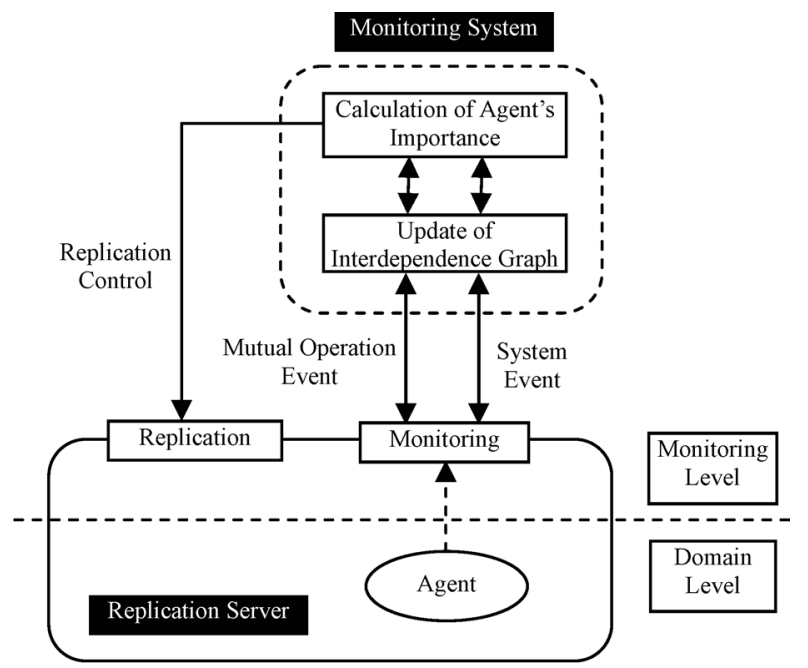

Fig. 2. Adaptive multiagent architecture 


\begin{abstract}
論 文
エージェントの相互依存関係を用いた適応型高信頼性システム

\author{
非会員 谷元 昭文* 正 員 松本 啓之亮* \\ 非会員 森 直樹*
}

An Adaptive and Reliable System Based on Interdependence between Agents

Akifumi Tanimoto*, Non-member, Keinosuke Matsumoto*, Member, Naoki Mori*, Non-member

A multiagent system (MAS) has recently gained public attention as a technique to solve competition and cooperation in distributed systems. However, MAS's vulnerability due to the propagation of failures prevents from applying to a large scale system. Then, this paper proposes a general composition technique to improve its reliability easily applied to the existent MAS. Proposed system monitors messages between agents to detect undesirable behaviors (failures). Collecting related information, the system generates global information of interdependence between agents and expresses it in a graph. This interdependence graph enables us to detect or predict undesirable behaviors. This paper also shows that the system can optimize performance of MAS and improve adaptively its reliability under complicated and dynamic environment by applying the global information acquired from analysis of the interdependence graph to a replication system.
\end{abstract}

キーワード : 信頼性，ロバスト，相互依存グラフ，モニタリング，レプリケーション，知能システム

Keywords : Reliability, Robust, Interdependence graph, Monitoring, Replication, Intelligent systems

\section{1. はじめに}

近年，情報家電などの進展によるユビキタスネット社会 では，我々を取り囲む多くの機器やシステムがお互いに協 調しあい，サービスを提供する。そのための技術としてマ ルチェージェントシステム ${ }^{(1)}$ (Multiagent System: MAS) が 注目されている。しかしマルチエージェントシステムは故 障の伝播による脆弱性のために，実際に稼動しているシス テムは小規模にとどまっているのが現状である。情報家電 などの進展によるユビキタスネット社会のインフラ構築に は，大規模なマルチエージェントの信頼性を高めることが 必要不可欠である。そこで本論文では，既存のマルチエー ジェントシステムに対し，容易にその信頼性を向上させる ための一般的な構成手法を提案する。

提案するシステムでは，故障などの予期しない振舞いを 検出するためにエージェントとエージェントの間のメッセ ージをモニタリングする。これにより, 関連情報の取得と 保存, 望ましくない状態の検出と予測など得られた情報か らエージェントの相互依存関係をグラフで表現した大域的 な情報を生成し，この相互依存グラフの分析から得られた 大域的な情報をレプリケーションシステム ${ }^{(2)}$ に応用するこ

\footnotetext{
* 大阪府立大学大学院工学研究科知能情報工学分野 干 599-8531 大阪府堺市学園町 1-1

Dept. of Computer Science and Intelligent Systems, Graduate

School of Engineering, Osaka Prefecture University,

1-1 Gakuen-cho, Sakai, Osaka 599-8531
}

とで，マルチエージェントシステムにおいて複雑かつ動的 な環境に適応的に信頼性を向上させることが実現できるこ とを示す。

レプリケーションシステムは，同じ内容の複製 (レプリ カ)をネットワーク上に複数配置するため, 既存のシステム のコードを大幅に変更する必要がなく, 分散システムの耐 故障性を容易に向上させる効果的な手法であることが知ら れている。このようなシステムは耐故障性をもつアプリケ ーションを実現するために故障エージェントと置き換わる レプリカをもつ。しかし, それらはレプリカ数の増加に伴 ってレプリケーションコストが増大するために, 大規模な 環境下においては適さない。

したがって本論文では, 環境の変化に適応し, 動的に変 化するマルチェージェントシステムにおいて, レプリケー ションによるコストを効率的に抑えパフォーマンスを向上 させることができる動的なレプリケーションシステムおよ びレプリケーションポリシーについても提案する。

\section{2. 従来手法の問題点}

〈2·1〉従来のモニタリング手法モニタリングとは 故障のような望ましくない振舞いが存在するシステムにお いて，信頼性を向上させたマルチェージェントシステムを 設計するために用いられる手法であり, いくつかの手法(3) (5) が提案されている。これらの手法の問題点を以下に示す。 
免疫型ネットワーク ${ }^{(3)}$ は, 自己診断型であるためエージェ ントが局所的にもつ知識に依存する点, および而故障性と パフォーマンスがネットワークの設計に依存するため, シ ステムが複雑になるという問題点がある。

また, Kaminka らの手法 ${ }^{(4)}$ は, 状態の不一致を同定するた めに手続き型のプラン認識モデルをベースにした手法であ るが，これは用いるプランが静的で，かつ閉じたシステム を前提としているため, 環境の変化に適応できないという 問題点がある。

最後に, Horling らの手法 ${ }^{(5)}$ は, 故障モデルを用いた分散 システムの診断手法である。これはパフォーマンスが局所 的に最適化されているが，大域的には最適化されていない ため, 大規模かつリアルタイムでエージェントの追加や削 除が行われるオープン環境下におけるマルチエージェント システムには適さない。また, 免疫型ネットワークと同様 にエージェントが局所的にもつ知識に依存するためエージ エントレベルでのモニタリングしか対処することができな いという問題点がある。

\section{3. 相互依存グラフを用いたモニタリング手法}

この章では，まずェージェント間の通信状況を表すため のデータモデルとして「相互依存グラフ」を導入する。次 に，それを使ったエージェントモニタリングアーキテクチ ヤを提案し, そのアーキテクチャにおける相互依存グラフ の計算アルゴリズムを示す。

4 章では, このように計算された相互依存グラフを使って, レプリケーションを制御する手法を示す。

〈3·1〉 相互依存グラフ 図 1 のようにドメインのエ ージェントをそれぞれノードに関連付け, ラベル付けされ た $(N, L, W)$ で表現して, これを相互依存グラフと呼ぶ。 $N$ はグラフのノード集合， $L$ はリンク集合，W はラベル集合 である。

$$
\begin{aligned}
& N=\{N i\} i=1, \ldots, n \\
& L=\{L i, j\} i=1, \ldots, n, j=1, \ldots, n \\
& W=\{W i, j\} i=1, \ldots, n, j=1, \ldots, n
\end{aligned}
$$

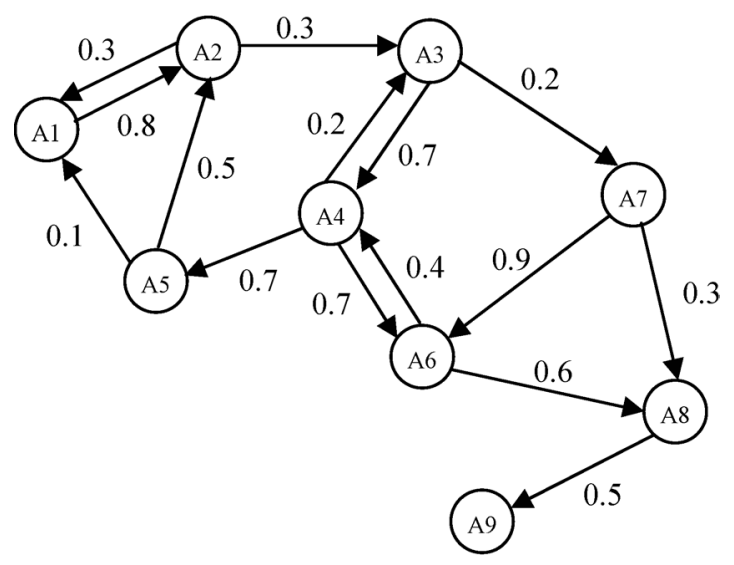

図 1 相互依存グラフ

Fig. 1. Interdependence graph.
ただし， $n$ はノード数である。Li,j は, ノード $N i$ から Nj へのリンクであり, Wi,j は $L i, j$ でラベル付けされた重み（実 数值）である。Wi,j は関連するエージェント $i, j$ 間の相互依 存の重要度を反映させたものである。

〈3·2〉 モニタリングアーキテクチャモニタリング は相互依存グラフを更新するための情報の取得と, ドメイ ンエージェント(Domain Agent)を制御するためのグラフ分 析の 2 つのプロセスから構成される。この情報とは, 例え ば通信負荷やエージェントの役割等である。

既存のマルチェージェントアーキテクチャのほとんど は, 観測メカニズムが集中化されており, 取得した情報は システムの振舞いを修正, もしくは解析するためにオフラ インで使用される。このため, これらの集中化されたモニ タリングアーキテクチャは, 観測された情報が環境の変化 に対してリアルタイムに適応できないため, 大規模かつ複 雑なシステムに適さない。従って本論文では, 大規模かっ 複雑なシステムの環境の変化にリアルタイムに適応させる ために観測メカニズムを分散させたモニタリングアーキテ クチャを提案する。その構成を図 2 に示す。

この分散観測メカニズムは, 環境変化に対して適応的に 反応するエージェントの組織構成に対応する。モニタリン グレベルにある反応的なエージェントは以下の 2 つの役割 をもつ。

・ドメインエージェントの観測と制御

- 大域的情報の生成

これら 2 つの役割は，ドメインのエージェントをモニタリ ングする監視エージェント(Monitoring Agent) と, 監視エージ ェントを管理するホストモニタェージェント (Host Monitoring Agent)との 2 種類のエージェントに関連づけられ る。監視エージェントは各ドメインェージェントに，ホス トモニタエージェントは各監視エージェントにそれぞれ関

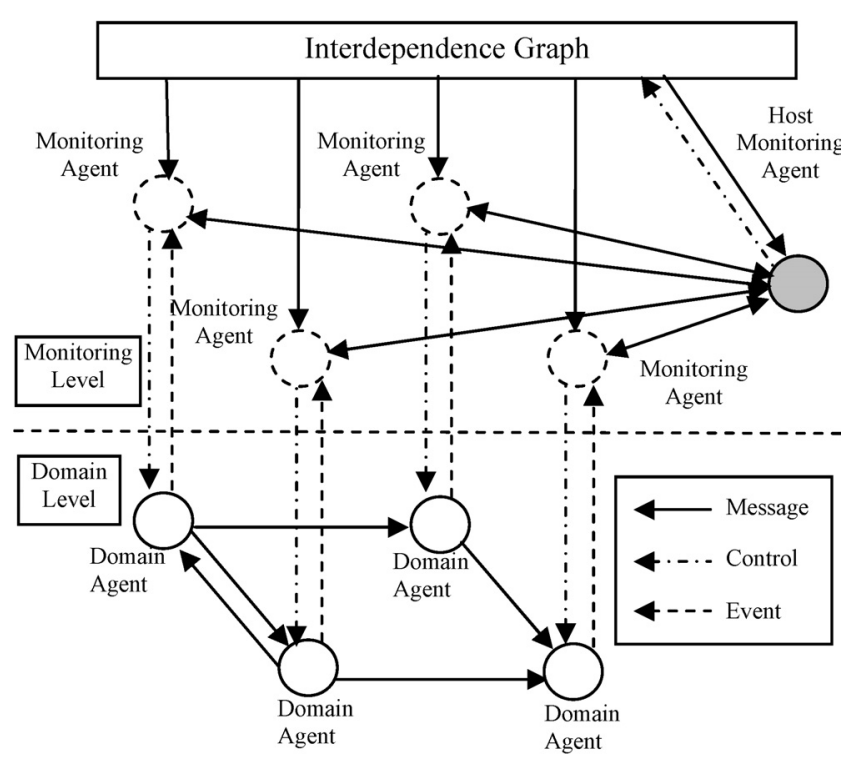

図 2 モニタリングアーキテクチャ

Fig. 2. Monitoring architecture. 
連付けられる。このモニタリングシステムにおいてそれを 構成するエージェントは 3 階層の構造をもつ。それぞれの 監視エージェントは 1 つのホストモニタエージェントのみ と通信を行い，モニタリングにより得た局所的情報を送信 する。ホストモニタエージェントは，監視エージェントが モニタした個別の情報を収集し, これらを大域的情報(大域 的なメッセージ数や交換された情報量等)にまとめる。

監視エージェントはドメインエージェントの様々な変化 を相互依存グラフに反映させる。また，エージェント環境 はリアルタイムで変化するため, このグラフは静的ではな くドメインのエージェントが追加，もしくは削除された場 合は動的に更新される。例えば新規のドメインエージェン トが追加され, 既存のドメインエージェントと通信を行う 場合には，この既存のエージェントをモニタする監視エー ジェントが新規のドメインエージェントを認識し，その結 果をホストモニタエージェントに連絡する。それを受けて ホストモニタエージェントが新規ドメインエージェントの 監視エージェントを追加する。

〈3·3〉重み更新アルゴリズム＼cjkstart重み更新アルゴリズ ムに用いる指標を以下に示す。

・モニタリングの時間インターバル $\Delta t$

・ 通信負荷 $Q(\Delta t)$

$Q(\Delta t)=$ operator $1(Q 1,1(\Delta t), \ldots, Q n, n(\Delta t))$

・ 送信メッセージ数 $N M(\Delta t)$

$N M(\Delta t)=$ operator $2(N M 1,1(\Delta t), \ldots, N M n, n(\Delta t))$

$Q i, j(\Delta t)$ および $N M i, j(\Delta t)$ は，それぞれ時間インターバル $\Delta t$ におけるエージェント $i$ から $j$ への通信量および送信メッセ ージ数を表す。operator は集合演算子であり。一般的なもの には平均演算がある。

相互依存グラフの重み $W i, j$ を更新する適応アルゴリズム の概要を以下に示す。このアルゴリズムは関連ノードを管 理するために各監視エージェントによって実行され, ホス トモニタエージェントに結果が収集され最終的に相互依存 グラフに反映される。

実行ステップ：

1. エージェント $j(j \neq i)$ について以下を繰り返す

2. 式(6), (7) の計算

Qtemp $=(Q i, j(\Delta t)-Q(\Delta t)) / Q(\Delta t)$

$N M t e m p=(N M i, j(\Delta t)-N M(\Delta t)) / N M(\Delta t)$

3. 重み $W i, j$ の更新

$W i, j(t+\Delta t)=W i, j(t)+\alpha \times$ operator3 $($ Qtemp, NMtemp $)$

4. 繰り返しの終端

ここでパラメータ $\alpha$ は, 既存の重みに対して新しく算出 した重みをどれくらいの割合で反映させるか決める割引率 である。環境の変化に対して重みを敏感に反応させる場合 はこのパラメータを高く設定し, 経験的に得られたデータ を重視する場合はこれを低く設定する。operator3 は集合演 算子である。

また，上記の提案アルゴリズムでは通信負荷 $Q(\Delta t)$ と送
信メッセージ数 $N M(\Delta t)$ の 2 種類の情報のみ扱った。ここで は重要度の基準として情報の処理量を取った。これ以外に もメッセージ経路の確保から相互依存グラフの連結性など が考えられるが, operator の内容を変更することにより, こ れらの要素を加味することができる。つまりこのアルゴリ ズムでは，指標として用いる情報を容易に拡張できるよう になっている。

\section{4. 適応型マルチェージェントアーキテクチャ}

〈4·1〉 アーキテクチャ 提案する適応型マルチエー ジェントアーキテクチャを図 3 に示す。このアーキテクチ ヤは, ドメインのマルチエージェントシステムとレプリカ を管理するレプリケーションサーバ(Replication Server)と前 章のモニタリングシステム(Monitoring System)で構成され る。

〈4·2〉 レプリケーションポリシーレプリケーショ ンポリシーとは, エージェントの状態や送受信メッセージ 等のバックアップをどのようにして保存しておくかという 方針である。一般的に用いられるレプリケーションポリシ 一には以下の 3 種類がある。

・アクティブ型

・パッシブ型

・ セミアクティブ型

アクティブ型は, 他のエージェントから受け取ったメッ セージを連続して全てのレプリカに対し送信するレプリケ ーションポリシーである。次に, パッシブ型はレプリカに 対し一定の周期で定期的に状態を送信するタイプであり, セミアクティブ型は 1 つの代表的なリーダーレプリカを決 め，そのリーダーレプリカが受け取ったメッセージをアク ティブ型と同様に他のレプリカに連続して送信するタイプ である。

その特徴としてアクティブ型は全てのレプリカがメッセ ージレベルで同期しているために, 復旧のための切り替え をスムーズに行うことができる利点があるが，そのレプリ

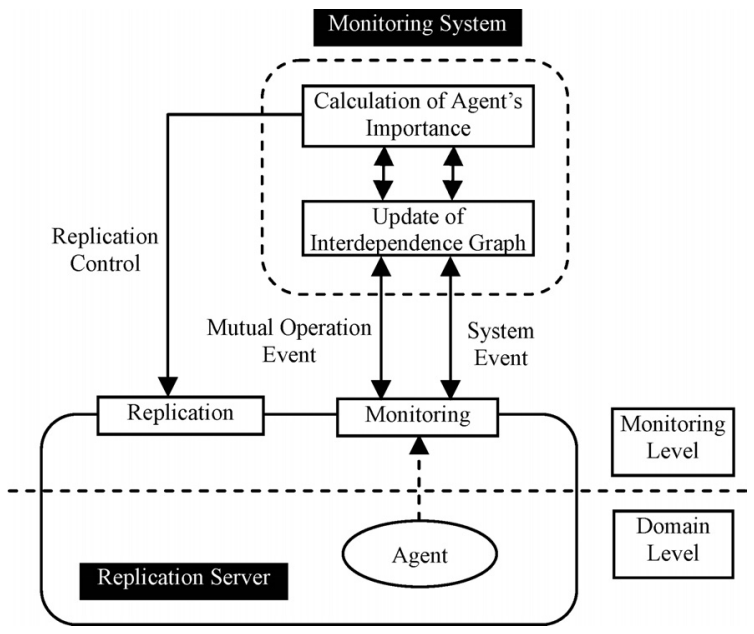

四 3 適応型マルチェージェントアーキテクチャ

Fig. 3. Adaptive multiagent architecture. 
ケーションコストが大きいという欠点がある。逆にパッシ ブ型は任意のインターバルでバックアップを行うことがで きるため，そのレプリケーションコストが小さいという利 点がある一方，他のエージェントに対してバックアップ時 点から故障時点までのメッセージを再送してもらう必要が あるため復旧のための切り替えがスムーズに行うことがで きないという久点がある。また，セミアクティブ型はアク ティブ型とパッシブ型の中間的な特徵をもつ。

〈4·3〉適応型レプリケーションシステム 提案シス テムとして, システムレベルでの効率性を改善するために 動的にレプリケーションポリシーを切り替えられるアーキ テクチャを考える。具体的には，パッシブ型とセミアクテ イブ型の 2 種類のレプリカを用いて, ドメインエージェン トおよびいくつかのレプリカからなるレプリケーショング ループを形成する。レプリケーショングループにおけるリ ーダーレプリカが故障した場合, 他のレプリカを新しくリ ーダーレプリカに切り替えることでシステムの復旧を行 う。レプリケーショングループを管理するレプリケーショ ンサーバは, 以下のプロセスを常時実行する。

まず, レプリカの生成日時, およびバックアップデータ の一致度を算出してレプリカを評価する。この一致度が高 いレプリカがドメインのエージェントおよびリーダーレプ リカが故障した場合に，新しいリーダーレプリカとして選 択される。次にレプリケーショングループをリスト形式で 表現して管理し，モニタリングシステムの指示で，レプリ カの生成や削除を行い，その結果をリストに反映させる。

\section{〈4·4〉相互依存関係を用いたレプリカ数決定アルゴリ}

ズム 相互依存グラフの分析は, エージェントの重要度 と故障の影響, マルチエージェントシステムの耐故障性を 把握することに役立つ。提案システムではエージェントの 重要性を評価するために, 各エージェントの入出力リンク にラベル付けされている重みWi,j t operator4 により集合演 算することでエージェントの重要度を算出する。その算出 式を式(9) に示す。ただし, $m$ はノード $i$ の次数とする。

$w i=$ operator $4(W i, j j=1, \ldots, m) \cdots$

また, エージェント $i$ の重要度 $w i$ は, 適応型レプリケー ションシステムにおいてレプリカの数 repi を算出するため に用いられる。その算出式を式(10) に示す。

repi $=$ round $\left[r_{0}+r_{\max } \times w i / W\right]$

ここで用いられるパラメータ $W$ は, 全エージェントの $w i$ の合計值, $r_{0}$ はレプリカ数の初期值, そして $r_{\max }$ は設計 者が設定するレプリカの総数の上限值である。

以上により, 各エージェントのレプリカの配置個数は環 境により重要度の高いエージェントに対して優先的に割り 当てられる。これはシステムリソースの効率化を図りなが ら, システム全体に影響を及ぼす重要なエージェントの故 障に強いシステムを実現できることを表す。

\section{5. シミュレーション実験}

本章では, 提案手法の有効性を検証するために行ったシ
ミュレーション実験について述べる。

〈5・1〉対象システム実験は, 仮想的な市場をシミ ュレートした eMarketマルチエージェントシステム(eMarket MAS)を対象とする。そのシナリオを以下に述べる。

1. 製品工場に属する部品購入エージェントが部品工場に 属する部品販売エージェントから部品を購入する。

2. 製品工場において購入した部品を加工し, 製品を作る。

3. 製品工場に属する製品販売エージェントが製品を小売 業者エージェントに売却する。

また，実験で用いる二段市場をモデル化したものを図 4 に示す。市場は次の 2 つが存在する。

・市場 A : 部品工場と製品工場間の取引

・市場 B : 製品工場と小売業者間の取引

さらに, 市場を構成するエージェントを役割で分類すると 次の 4 種類になる。

・販売エージェント(Sales Agent)

・購入エージェント(Purchasing Agent)

・購入・販売エージェント(Purchasing\&Sales Agent)

・市場管理エージェント(Market Management Agent)

販売および購入エージェントはそれぞれ部品や製品の販 売, 購入のみを行うエージェントである。購入・販売エー ジェントは各市場において異なる役割を果たすエージェン トであり，例えば製品工場に属するエージェントがこれに 該当する。最後に, 市場管理エージェントは各市場に 1 つ 存在し, 市場を構成するエージェントの登録や削除などの 管理を行う。また，オークション形式で行われる取引の仲 介を行い, その管理も行う。

表 1 に実験に用いた計算機の性能と実行するアプリケー ションを示す。Ethernet 上で接続された 3 台のマシンにおい て，それぞれ対象システムである eMarket MAS, レプリケ ーションサーバおよびフォールトジェネレータを実行し, そのうちマシン A にのみモニタリングシステムを実行させ る。また市場でのオークション形式による取引は以下のプ ロセスで行う。

1. 販売エージェントが最低販売価格を市場管理エージェ ントに提示する。

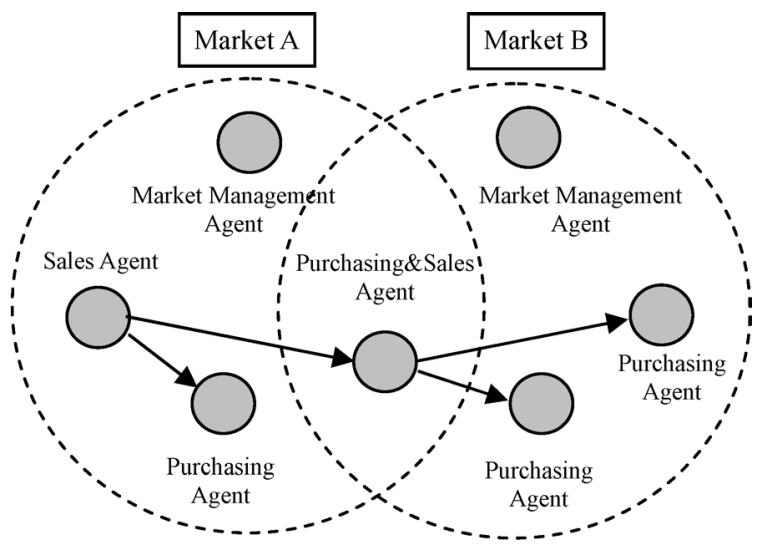

図 4 二段市場モデル

Fig. 4. Two stage market model. 
表 1 各マシンのスペックと実行するシステム

Table 1. Specifications of each machine and running systems.

\begin{tabular}{|l|l|l|}
\hline & Specifications & Running Systems \\
\hline Machine A & $\begin{array}{l}\text { Intel Pentium4 3.4GHz } \\
\text { Memory 1GB }\end{array}$ & $\begin{array}{l}\text { Replication Server } \\
\text { Monitoring System } \\
\text { eMarket MAS } \\
\text { Fault Generator }\end{array}$ \\
\hline Machine B & $\begin{array}{l}\text { AMD Athlon 1.2GHz } \\
\text { Memory 512MB }\end{array}$ & $\begin{array}{l}\text { Replication Server } \\
\text { eMarket MAS } \\
\text { Fault Generator }\end{array}$ \\
\hline Machine C & $\begin{array}{l}\text { Intel Celeron 1GHz } \\
\text { Memory 256MB }\end{array}$ & $\begin{array}{l}\text { Replication Server } \\
\text { eMarket MAS } \\
\text { Fault Generator }\end{array}$ \\
\hline Network & 100Base-T Ethernet & \\
\hline
\end{tabular}

2. 市場管理エージェントは一定時間, 購入エージェントか らの入札を受け入れる。

3. 入札締め切り後, 市場管理エージェントは最低販売価格 を超える入札のなかで，最も高い入札価格を提示した購 入エージェントとの取引を成立させる。

4. 該当する入札がない場合，取引は不成立とし販売エージ ェントは先の販売価格を下回る価格を再び提示する。

価格提示と入札のタイミングおよび販売価格と入札価格 は一様乱数により決定する。

フォールトジェネレータによる故障の生成については一 様乱数により決定したエージェントに停止故障を発生させ る。以上の条件下のシステムにおいて，耐故障性とパフォ ーマンスの二点について検証を行う。

〈5・2〉実験 1 実験 1 の目的は, あらかじめシステム 設計者が設定するパラメータであるレプリカの総数 $r_{\max }$ と システムの信頼性との関係を明らかにすることである。

$\langle 5 \cdot 2 \cdot 1\rangle$ 実験条件 実験は, 10 分間のシミュレーシ ヨンにおいてフォールトジェネレータにより計 100 個の故 障を発生させ，レプリカの総数 $r_{\max }$ を 0 から 30 まで 2 ずつ 変化させた時のシミュレーション成功回数を測定する。

シミュレーションは計 40 回行い, その成功の割合で評価 を行う。実験に用いるパラメータは表 2 のとおりである。

\section{$\langle 5 \cdot 2 \cdot 2\rangle$ 実験結果と考察実験結果を図 5 に示す。} $r_{\max }$ を 10 に設定した場合は，成功率は $80 \%$ に達し，20 以 上に設定すると成功率 $100 \%$ となった。つまり，この実験 環境の場合は $r_{\max }$ を 20 以上に設定することでシステムの信 頼性を維持できることを表し，かつレプリケーションコス 卜を効率的に抑えることができる可能性があることを示し ている。他のケースについても同様な傾向が見られた。

このパラメータ $r_{\max }$ は, システムにとって重要なパラメ ータであり，適切な值を設定しなければならない。

$\langle 5 \cdot 3\rangle$ 実験 2 実験 2 の目的は, システムのパフォー マンスに影響を与える要素となるモニタリングコストにつ いて検証する。

$\langle 5 \cdot 3 \cdot 1\rangle$ 実験条件実験は，まずモニタリングを行 う場合と行わない場合で，実行に要する処理時間(Execution time)によりパフォーマンスを計測する。

市場を構成するエージェント数は 100 から 350 まで 50 ず
表 2 実験 1 で用いるパラメータ

Table 2. Parameters applied to experiment 1.

\begin{tabular}{|l|r|}
\hline Number of Agents & Total 100 \\
\hline (Market Management Agents) & 2 \\
(Purchasing\&Sales Agents) & 50 \\
(Purchasing Agents) & 24 \\
(Sales Agents) & 24 \\
\hline Monitoring Interval & $500 \mathrm{~ms}$ \\
\hline Discount Rate $\alpha$ & 1.0 \\
\hline Initial Number of Replica $r_{0}$ & 1 \\
\hline
\end{tabular}

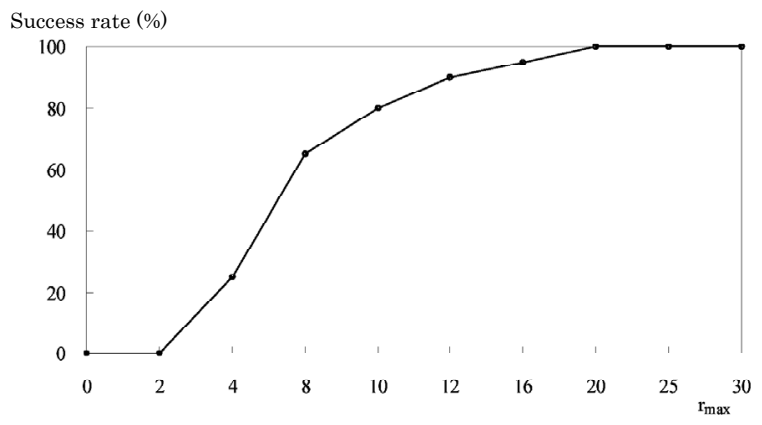

図 $5 r_{\max }$ によるシミュレーション成功率の違い

Fig. 5. Relationship between $r_{\max }$ and success rate.

表 3 実験 2 で用いるパラメータ

Table 3. Parameters applied to experiment 2.

\begin{tabular}{|c|c|}
\hline Agents & \\
\hline (Market Management Agents) & 2 \\
(Purchasing\&Sales Agents) & $50 \%$ \\
(Purchasing Agents) & $25 \%$ \\
(Sales Agents) & $25 \%$ \\
\hline Monitoring Interval & $500 \mathrm{~ms}$ \\
\hline Discount Rate $\alpha$ & 1.0 \\
\hline Total Number of Replicas $r_{\max }$ & 30 \\
\hline
\end{tabular}

つ変化させ，実験 1 と同様にエージェントの構成は市場管 理エージェンを 2 つに固定し，残りを表 3 の割合で配置す る。故障は, 実験 1 と同様に 10 分間のシミュレーションに おいてフォールトジェネレータにより計 100 個の故障を発 生させる。実験に用いるパラメータは表 3 のとおりである。

〈5·3·2〉実験結果と考察提案システムでモニタリ ングした場合としない場合のパフォーマンスの計測結果を 図 6 に示す。

両者の差がモニタリングコストに相当するが，エージェ ント数が増加した場合でも，モニタリングにより急激にパ フォーマンスが悪化することなく, 一定のコストで増加し ていることが分かる。

また，従来の代表的なモニタリングシステムである免疫 型ネットワークとレプリケーションシステムを組み合わせ た従来システムとパフォーマンスを比較した。眓 6 の結果 より, 提案システムによるモニタリングコストは問題にな らない程度であることが分かる。

さらに, エージェント数が増加すると, 従来システムは 相互診断を構成するエージェントが増加するためパフォー 


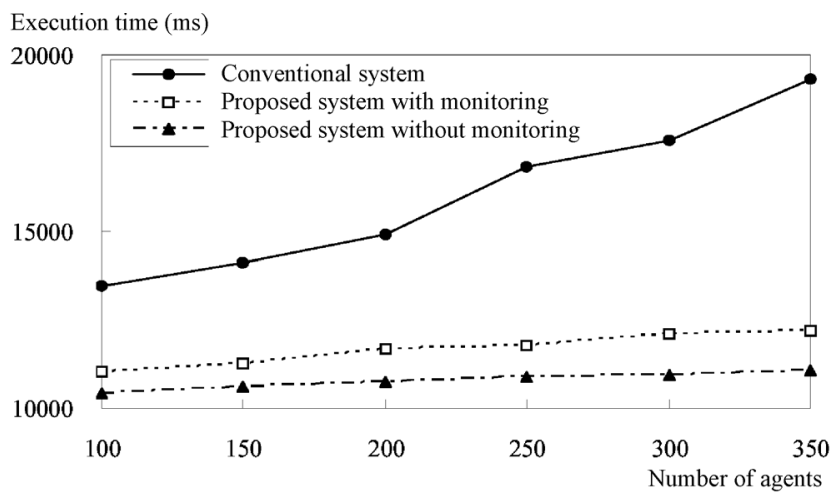

図 6 モニタリングコスト

Fig. 6. Monitoring cost.

マンスが大幅に悪化することも読み取れる。免疫型ネット ワークの診断領域を縮小寸ることでパフォーマンスは若干 改善すると考えられるが，逆に故障の決定に必要な信頼度 計算の収束に時間を要するため, 信頼性を維持できなくな る。これは提案システムが大規模なマルチエージェントシ ステムのモニタリングシステムとしてモニタリングコスト の面からも適することを裏付けるものである。

\section{6. まとめ}

本論文は，マルチエージェントシステムにおいてェージ エント間の相互依存関係を大域的に表現した相互依存グラ フを導入することにより，システムレベルでの解析が行え る大域的モニタリング手法を提案した。さらに，モニタリ ングにより得た大域的情報をマルチエージェントシステム の耐故障性の向上に利用した適応型レプリケーションシス テムを提案した。

また，実験としてマルチェージェントシステムを仮想的 に表現した eMarket MAS を対象に提案手法を適用し，有効 性の検証を行った。本手法の効果は, 単位処理量当たりの 故障発生率がほぼ等しい均質なエージェントからなるマル チエージェントシステムに対して, 害行時の処理量を監視 することにより，効率的に発揮できるものと考えられる。 また， $r_{\max }$ の設定については，ドメインエージェントの故障 率とも関係寸るので，類似のシステムからの推定值や過去 の経験からの推定值を用いて設定することが必要になる。 これらについては，さらなる検討が必要である。

今後の課題としては, 次のようなものが挙げられる。

・重み更新アルゴリズムに用いる集合演算子の拡張

例えば，過去の重要度に対寸る現在の重要度の学習度合 い

・相互依存グラフに用いる局所的情報の拡張

例えば，メッセージの種類の抽出，分類，およびその評 価と重み付けやメッセージ系列の評価

・レプリケーショングループにおけるレプリケーションポ リシーの動的な切り替え手法

(平成 17 年 6 月 21 日受付, 平成 17 年 11 月 4 日再受付)

\section{文献}

(1) G. Weiss : "Multiagent systems -A modern approach to distributed artificial intelligence-", The MIT Press, pp.79-120 (1999)

(2) K. Hagihara : "Algorithms for fault-tolerant distributed systems", Information Processing Society of Japan Magazine, Vol.34, No.11, pp.1336-1340 (1993-11) (in Japanese) 萩原兼一：「フォールトトレラント分散システム向けアルゴリズム 概論」，情報処理, 34, 11, pp.1336-1340 (1993-11)

(3) Y. Ishida : "An immune network approach to sensor-based diagnosis by self-organization", Complex Systems, Vol.10, No.1, pp.73-90 (1996)

(4) G. A. Kaminka, D. V. Pynadath, and M. Tambe : "Monitoring teams by overhearing: A muti-agent plan-recognition approach", Intelligence Artificial Research, Vol.17, pp.83-135 (2002)

(5) B. Horling, B. Benyo, and V. Lesser : "Using self-diagnosis to adapt organizational structures", Proc. of 5th International Conference on Autonomous Agents, pp.529-536 (2001)

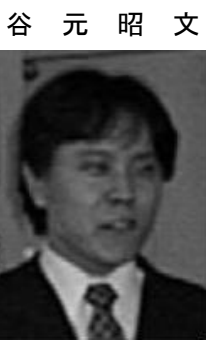

（非会員） 2005 年 3 月大阪府立大学大学院工学 研究科電気 - 情報系専攻博士前期課程修了。現 在, 富士火災システムサービスに勤務。在学中, マルチェージェントシステムの信頼性に関する 研究に従事。

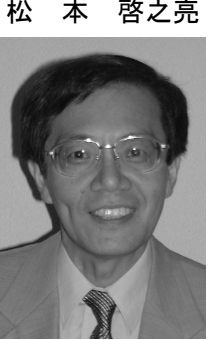

（正員） 1978 年 3 月京都大学大学院工学研究 科精密工学専攻修士課程修了。同年 4 月三菱電 機 (株)入社。1996 年大阪府立大学工学部情報工 学科教授。現在, 大阪府立大学大学院工学研究 科教授。主に, 知能情報処理やソフトウェアに 関する研究に従事。工学博士。1984 年電気学会 論文賞, 2005 年進歩賞受賞。情報処理学会, IEEE などの会員。

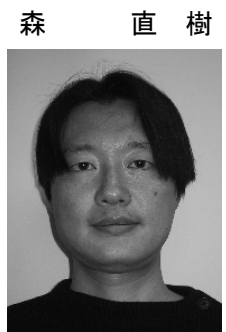

(非会員) 1994 年 3 月京都大学大学院工学研究 科原子核工学専攻修士課程修了。1997 年 3 月同 大学院工学研究科電気工学専攻博士後期課程 指導認定退学。同年 4 月大阪府立大学工学部情 報工学科助手。現在, 同大学院工学研究科講 師。主に, 遺伝アルゴリズムの研究に従事。工 学博士。1999 年システム制御情報学会論文賞受 賞。 